\title{
EKSISTENSI KERAJINAN PERAK KOTO GADANG SUMATERA BARAT
}

Hendra ${ }^{1}$ (doankhendra7@gmail.com, Program studi Seni Kriya ISI Padangpanjang)

\begin{abstract}
Koto Gadang Silverwork is located in District IV Koto Agam Regency which is one of the craft centers that exist near Bukittinggi. The existence of silver handicraft products that produced in Koto Gadang has started since the Dutch colonial era until now. Silver handicrafts grow and develop according as the time continue. This can be seen from changes in the function and shape of existing silver handicrafts that equal with the changes of the community. Silver handicraft products Koto Gadang can be classified into jewelry products such as necklaces and bracelets, as well as souvenir products such as miniature of clock tower. The products that produced by craftsmen are represent of their existence and their efforts to adjust the products to public demand. To maintain the quality of silver products, craftsman only sell the products in a limited market. This way is taken to maintain public confidence in the silver craft itself. With cultural changes, the silver handicrafts Koto Gadang face the challenges and obstacles that make artman must be clever in maintaining consumer confidence. This is closely related to the survival of silverwork itself around the supporting community.
\end{abstract}

Keyword : existence, silver, Koto Gadang

ABSTRAK

Kerajinan perak Koto Gadang terletak di Kecamatan IV Koto Kabupaten Agam yang merupakan salah satu sentra kerajinan yang ada di dekat Kota Bukittinggi. Eksistensi produk kerajinan perak yang dihasilkan Koto Gadang sudah dimulai semenjak zaman penjajahan Belanda hingga sekarang. Kerajinan perak tumbuh dan berkembang sesuai dengan perkembangan zaman. Hal ini dapat dilihat dari perubahan fungsi dan bentuk kerajinan perak yang ada yang menyesuaikan dengan perubahan masyarakatnya. Produk kerajinan perak Koto Gadang bisa dikelompokkan menjadi produk perhiasan, seperti kalung dan gelang, serta produk cenderamata, seperti miniatur Jam Gadang. Produk yang dihasilkan oleh perajin merupakan bentuk eksistensi mereka dan usaha mereka untuk menyesuaikan produk yang dihasilkan dengan permintaan masyarakat. Untuk menjaga kualitas produk kerajinan perak tersebut, perajin hanya menjual produk yang dihasilkan dalam pasar yang terbatas. Hal ini dilakukan untuk menjaga kepercayaan masyarakat terhadap kerajinan perak itu sendiri. Seiring perubahan budaya mengakibatkan kerajinan perak Koto Gadang menghadapi tantangan dan hambatan yang membuat perajin harus pandai-pandai dalam menjaga kepercayaan konsumen. Hal ini berhubungan erat dengan keberlangsungan kerajinan perak itu sendiri di masyarakat pendukungnya.

Kata Kunci : eksistensi, perak, Koto Gadang 


\section{PENDAHULUAN}

Sumatera Barat memiliki perupa yang mengandalkan oral tradition dalam sejumlah sentra seni kerajinan, baik yang sudah berkembang saat ini maupun yang kurang produktif lagi. Seperti dikemukakan oleh Usman bahwa:

Dalam dua abad terakhir di Sumatra Barat telah banyak melahirkan perupa-perupa yang mengandalkan oral tradition warisan pendahulu mereka. Para perupa tersebut telah memproduksi benda-benda kegunaan sehari-hari, seperti anyaman pandan, anyaman rotan, tenunan songket, ukiran kayu, tembikar, kriya logam dan lainnya dengan bentuk, fungsi, sifat bahan, metode anggitan serta penerapan nilai artistik yang berhasil dipadu hingga menjadi kesatuan yang harmonis disetiap karya mereka, dalam kapasitas asri, harmoni dan penuh makna (1994:6).

Hasil karya yang dihasilkan para perajin Sumatra Barat itu memang terbatas pada benda seni kerajinan sebagai bagian applied art yang hingga kini terus berkembang. Seperti seni kerajinan perhiasan emas, perak, dan sulaman di Koto Gadang Bukittinggi, tembikar di Galogandang, anyaman di Payakumbuh, pandai besi di Sungai Puar, seni kerajinan tenun dan ukir di Pandai Sikek, sulaman benang emas di Nareh Pariaman dan Lubuk Begalung Padang. Bendabenda seni kerajinan yang dihasilkan masingmasing daerah itu memiliki prospek sebagai comodity export dan home industry begitu pun dengan kerajinan perak.

Teknik pembuatan kerajinan perak Koto Gadang hampir sama dengan kerajinan perak yang ada di daerah lain di pulau Jawa, yaitu Kota Gede. Kota Gede dan Koto Gadang tidak hanya memiliki nama yang sama tapi juga sama-sama daerah yang menghasilkan kerajinan perak. Kerajinan perak merupakan salah satu seni tradisi yang menjadi ciri khas budaya nagari Koto Gadang. Dahulu kerajinan perak bagi masyarakat Koto Gadang dipakai untuk perlengkapan adat perkawinan, yaitu pada perhiasan wanita Koto Gadang, seperti gelang, kalung, anting, dan cincin. Namun, pada saat sekarang ini kerajinan perak tidak hanya dipakai untuk keperluan upacara adat tetapi juga dipakai untuk keperluan seharihari, seperti pajangan di meja, miniatur, cincin, kalung, gelang, dan bros.

Kerajinan perak yang dihasilkan di Koto Gadang memiliki keindahan dan kehalusan yang tak kalah dari kerajinan perak kota lain di Indonesia. Kerajinan perak dari Koto Gadang Agam memiliki ciri khas tersendiri dari segi tampilannya. Jika dilihat dari dekat, penampilannya tidak begitu berkilau namun memiliki kesan yang sangat halus, dengan warna mirip warna putih susu. Kesan keseluruhannya menjadi elegan, anggun namun tidak mencolok mata. Karena kehalusan pembuatannya, kerajinan perak ini cocok jika dipadukan dengan songket yang juga terkenal akan kehalusan bahan dan desainnya.

Selain itu produk kerajinan perak yang dihasilkan di Koto Gadang pada zaman dahulu menggunakan $100 \%$ perak murni yang membedakannya dengan kerajinan lainnya. Perak yang digunakan merupakan perak kualitas baik, sehingga setiap perajin perak selalu berusaha untuk menjaga kualitas produk yang dihasilkan. Bagi pengunjung, akan sangat sulit menemukan produk kerajinan perak Koto Gadang di pasaran. Hal ini merupakan bentuk strategi pemasaran yang dipilih oleh perajin guna menghadapi persaingan dengan berbagai produk perhiasan imitasi yang begitu banyak bermunculan.

Semenjak di mulainya pasar bebas Asia yang dikenal dengan Masyarakat Ekonomi Asia (MEA), persaingan dalam segala bidang akan semakin kompetitif, termasuk persaingan produk seni kerajinan. Berbagai 
produk seni kerajinan dari berbagai negara Asia bisa saja membanjiri pasar Indonesia. Hal ini tentu bisa saja menjadi ancaman nyata bagi produk kerajinan perak Koto Gadang yang masih bertahan dengan sistem tradisi. Oleh karena itu, perlu disiapkan suatu strategi pengembangan produk dengan desain yang lebih kontemporer, sehingga tetap bisa mewadahi keinginan dan selera masyarakat.

Untuk membahas masalah yang berkaitan dengan kerajinan perak di Koto Gadang ini digunakan metode penelitian kualitatif, karena akan menjawab persoalan tentang ciri-ciri fenomena dengan tujuan mendeskripsikan dan memahami fenomena dari sudut pandang tertentu. Untuk mengungkap fenomena kerajinan perak Koto Gadang ini digunakan pendekatan multidisiplin dengan mengembangkan analisis melalui perpaduan dua atau lebih disiplin ilmu (Gustami, 2003: 78).

Menata dan menyusun struktur pemikiran sesuai dengan kaidah ilmiah didasarkan pada pendekatan estetik sebagai pendekatan utama yang didukung dengan pendekatan lain, seperti pendekatan sosiologis dan antropologis. Pendekatan teoritis diperlukan dalam membahas secara keseluruhan masalah penelitian ini yang mencakup segi bentuk, struktur, proses pengerjaan, dan gaya seni kerajinan perak di tengah kehidupan masyarakat Koto Gadang. Sehubungan dengan beberapa pendekatan di atas, untuk mengkaji keberadaan dan eksistensi kerajinan perak di Koto Gadang secara kontekstual diperlukan pendekatan sosio-kultural. Dalam mengkaji bentuk, teknik, struktur seni dan produk yang dihasilkan menggunakan pendekatan estetik, untuk memahami latar belakang alam dan kondisi lingkungan perajin perak mengacu pada pendekatan antropologi etnografi (Koentjaraningrat, 1967: 7).
Populasi dalam penelitian ini adalah seluruh produk kerajinan perak di Koto Gadang, yaitu produk kerajinan perak yang dipakai pada perlengkapan adat perkawinan, yakni perhiasan yang dipakai oleh wanita Koto Gadang baik yang baru menikah maupun yang sudah lama menikah dan berupa perhiasan yang dipakai dalam kehidupan sehari-hari. Sehubungan dengan itu, tidak seluruh populasi dijadikan sampel penelitian, tetapi diambil beberapa yang dianggap dapat mewakili populasi. Pemilihan sampel ditetapkan dengan mempertimbangkan kebutuhan masyarakat pada saat sekarang ini.

Data yang berhubungan dengan topik penelitian, baik yang berkaitan dengan bentuk, struktur, proses produksi, dan gaya seni kerajinan perak, maka diambil sampel penelitian dengan teknik purposive sampling, yaitu pengambilan sampel yang disesuaikan dengan tujuan penelitian (Nawawi, 1990: 157). Dari seluruh produk kerajinan perak yang dihasilkan di Koto Gadang, produk yang dijadikan sampel yang dapat diidentifikasi secara jelas dan dapat diklasifikasi menurut waktu, teknik pembuatan, dan material. Berdasarkan tujuan penelitian, akan diambil beberapa produk yang berfungsi untuk perlengkapan adat, seperti kaluang yang dipakai oleh pengantin perempuan, dan gelang tangan. Produk untuk perhiasan dan kebutuhan sehari-hari, seperti miniatur, cincin, anting, pajangan di atas meja, termasuk yang berkenaan dengan sumber daya manusia, seperti perajin, pengusaha, serta lembaga-lembaga pendukung kerajinan perak di Koto Gadang.

Pengumpulan data dilakukan melalui sumber pustaka untuk mendapatkan bahanbahan yang berhubungan dengan objek penelitian, berupa buku, artikel, tesis, majalah, jurnal, katalog, dan lain-lain. R.M Soedarsono (1999:192) menjelaskan bahwa "data kualitatif untuk penelitian seni rupa juga 
bisa didapatkan dari sumber tertulis, sumber lisan, artefak, peninggalan sejarah, serta sumber-sumber rekaman."

Proses analisis dalam penelitian ini meliputi berbagai tahapan. Pertama identifikasi data, mengumpulkan data lisan, verbal dan data visual, baik yang diperoleh melalui studi pustaka, observasi, wawancara, maupun rekaman. Setelah identifikasi data diselesaikan, dilanjutkan dengan tahap kedua, yaitu mengadakan klasifikasi data dengan cara memilih atau mengelompokkan data penelitian yang telah diidentifikasi sesuai dengan jenis dan sifat data. Tahap ketiga adalah seleksi data, yaitu menyisihkan data yang kurang relevan dan tidak berkontribusi dalam analisis yang dikembangkan. Tahap keempat dilakukan analisis data sesuai dengan teori-teori yang sudah ditetapkan sebelumnya, baik menggunakan analisis tekstual maupun kontekstual, selanjutnya diungkapkan dalam bentuk karya tulis ilmiah. Menganalisis data dimulai dengan mengorganisasi data semenjak pengumpulan data dilakukan dan dikerjakan secara intensif setelah meninggalkan lapangan (Moleong, 2007: 280 - 281). Selanjutnya kondisi yang ada di lapangan dan data yang diperoleh dievaluasi dan terakhir dikembangkan dengan tujuan untuk membantu menghasilkan jawaban yang diinginkan. Hasil dari jawaban yang diinginkan dirumuskan dalam bentuk pola pikir, kemudian diinterpretasikan dan dimaknai sebagai kesimpulan.

\section{PEMBAHASAN}

\section{Sejarah Kerajinan Perak Koto Gadang}

Berbicara masalah sejarah kerajinan perak Koto Gadang ini, sangat sulit untuk menemukan bukti dan informasi valid mengenai awal masuknya kerajinan perak di Koto Gadang. Kerajinan perak koto Gadang diyakini sebagai kerajinan yang telah ada semenjak zaman kolonial belanda sekitar abad ke-19. Hal itu dikarenakan kerajinan perak lahir dan berkembang seiring dengan lahirnya usaha Amai Setia yang didirikan oleh RKY Rohana kudus. Perajin perak yang ada di Koto Gadang memiliki keahlian yang tersiar sampai ke negeri belanda. Pada masa itu salah seorang perajin perak yang bernama Datuak Mangkudun dipercaya untuk mengikuti pameran kerajinan perak yang diadakan di negeri Belanda. Sekembalinya dari Belanda, kerajinan perak Koto Gadang semakin berkembang dan banyak menarik minat masyarat kelas atas seperti warga Belanda.

Menurut keterangan yang didapatkan dari Asri (82 tahun) bahwasanya pengaruh penjajahan Belanda sangat besar dalam membantu perkembangan kerajinan perak tersebut. Seiring berjalannya waktu, orang Belanda yang ada di Bukittinggi dan sekitarnya sering memesan berbagai bentuk perhiasan perak dari perajin Koto Gadang. Pada masa tersebut perajin masih menggunakan peralatan yang sangat sederhana dalam proses peleburan biji perak dan dalam membentuknya. Sedangkan Asri sendiri mendapatkan kepandaian mengolah kerajinan perak dari ayahnya yang juga seorang perajin perak. Karena sering membantu ayahnya, lama kelamaan Asri sendiri juga bisa membuat beragam bentuk kerajinan perak tersebut.

Dari data yang diperoleh di lapangan dapat disimpulkan bahwa kerajinan perak Koto Gadang sudah ada semenjak zaman pemerintahan Belanda dan diperkirakan bahwa orang Belandalah yang membawa keahlian mengolah biji perak tersebut ke Koto Gadang seperti yang ada di Kota Gede Yogyakarta. Hal ini sangat mungkin terjadi dikarenakan pendudukan Belanda di Indonesia pada zaman dahulu meliputi seluruh wilayah NKRI, sehingga mudah sekali bagi mereka untuk membawa suatu kebudayaan dari suatu daerah ke daerah 
lainnya. Kerajinan perak Koto Gadang telah mengalami pertukaran zaman dari zaman Belanda, Jepang, dan sampai pada saat Indonesia merdeka. Seiring berjalannya waktu, maka kerajinan perak juga mengalami perubahan, baik dari segi bentuk, fungsi, maupun proses pembuatannya. Perubahan ini sangat logis karena seiring perkembangan zaman, maka kebudayaan tersebut juga akan mengalami perubahan. Hal ini sesuai dengan pepatah Minang yang menyatakan bahwa sakali aie gadang, sakali tapian barubah (sekali air besar, sekali tepian berubah). Budaya masyarakat dari waktu ke waktu akan mengalami perubahan dan pergeseran (Haryono, 2009: 12). Sejalan dengan perkembangan zaman maka perubahan zamanlah yang menyeret seni tradisi ke dalam sistem komersialisasi, sehingga akan berpengaruh terhadap karya itu sendiri.

\section{Proses Pembuatan Produk Kerajinan Perak Koto Gadang}

Kerajinan perak di Koto Gadang menghasilkan beragam bentuk produk kerajinan perak. Pada masa lalu kerajinan perak koto gadang hanya menghasilkan beberapa jenis produk kerajinan perak yang dipakai oleh anak daro dalam upacara pernikahan yaitu kalung, gelang, dan cincin (Syaifuddin, 1985: 111). Namun dalam perkembangannya anak daro mulai juga memakai subang dan anting yang dipakai secara bersamaan. Semua produk yang dipakai diproduksi sendiri oleh perajin perak Koto Gadang. Di Koto Gadang terdapat enam perajin yang masih aktif membuat produk kerajinan perak, yaitu "Welisyar silverwork," "Cici silverwork," "Leo silverwork," "Ari silverwork," "Deny dan Desi silverwork," serta "Lili Indah silverwork." Di antara keenam perajin tersebut, ada dua perajin yang pernah menjadi mitra binaan PT Semen Padang, yaitu "Leo silverwork" dan "Lili Indah Silverwork."
Jika dilihat secara keteknikan, proses pembuatan beragam produk perak yang dihasilkan di koto Gadang secara prinsipnya ada dua, yaitu perak dengan teknik felegree, motif yang dianyam dan perak dengan bentuk yang ditatah (pahat) (wawancara dengan Asri di Koto Gadang Tanggal 20 Agustus 2017). Perak dengan motif dianyam, seperti motif pada cincin tiga mata, bros, anting, kalung, gelang, dan miniatur rumah adat. Sedangkan produk perak yang ditatah contohnya cincin dengan batu akik. Keseluruhan produk yang dihasilkan oleh perajin perak Koto Gadang juga terjaga kualitasnya dengan menggunakan perak persentase 99\%. Komitmen untuk menjaga kualitas kerajinan perak ini sudah dilaksanakan oleh para perajin dari puluhan tahun yang lalu sampai sekarang, sehingga mereka tak pernah khawatir dengan banyaknya produk perhiasan dari daerah lain yang datang sebagai pesaing.

Peralatan yang dibutuhkan oleh perajin perak antara lain :

a. Palu;

b. Pinset dengan berbagai ukuran untuk memegang benang perak yang akan dianyam;

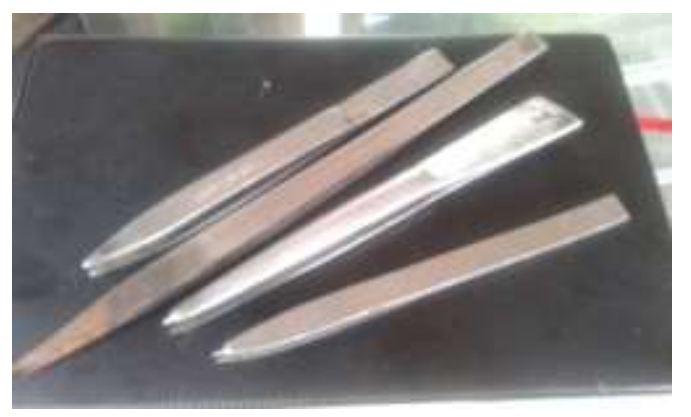

Gambar 1. Pinset untuk Memegang Gulungan Benang Perak. (Sumber Foto: Hendra, 2017)

c. Landasan untuk membentuk lempengan perak;

d. Gunting;

e. Kompor dengan pompa untuk meleburkan biji perak;

f. Tang penarik; 


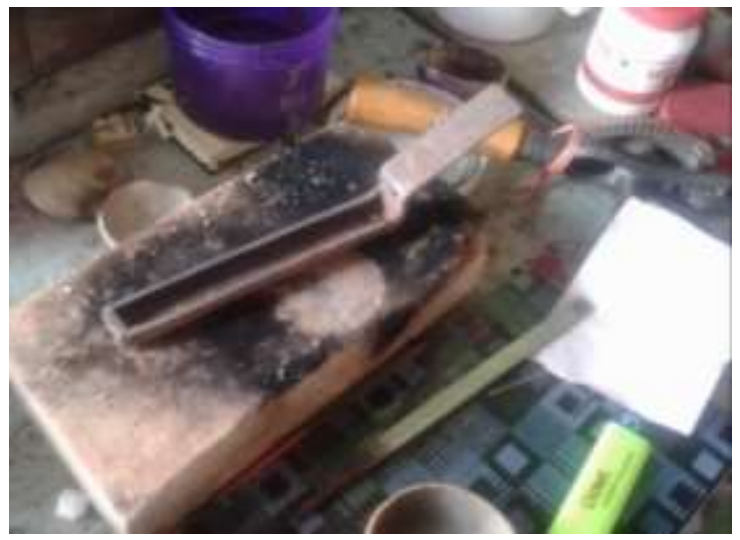

Gambar 2. Cetakan Pembentuk Lempengan Perak (Sumber Foto: Hendra, 2017)

g. Cetakan pembentuk perak;

h. Mal untuk membentuk benang perak;

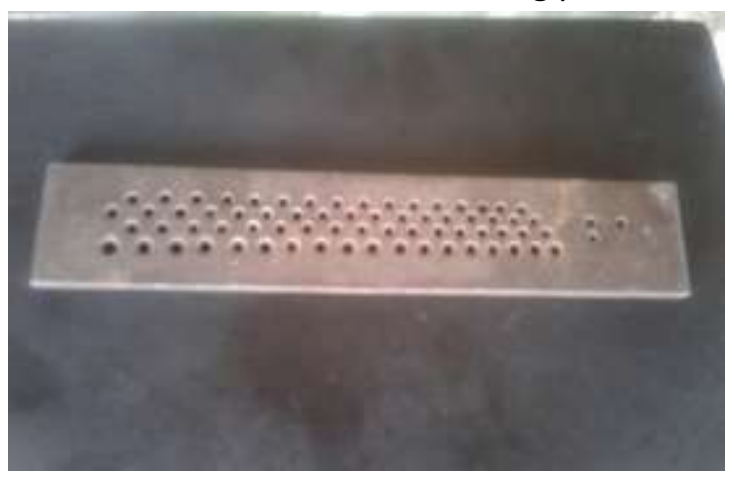

Gambar 3. Mal untuk Membuat Benang Perak

(Sumber Foto: Hendra, 2017)

i. Landasan pembentuk yang digunakan untuk membentuk lempengan perak menjadi bentuk yang diinginkan;

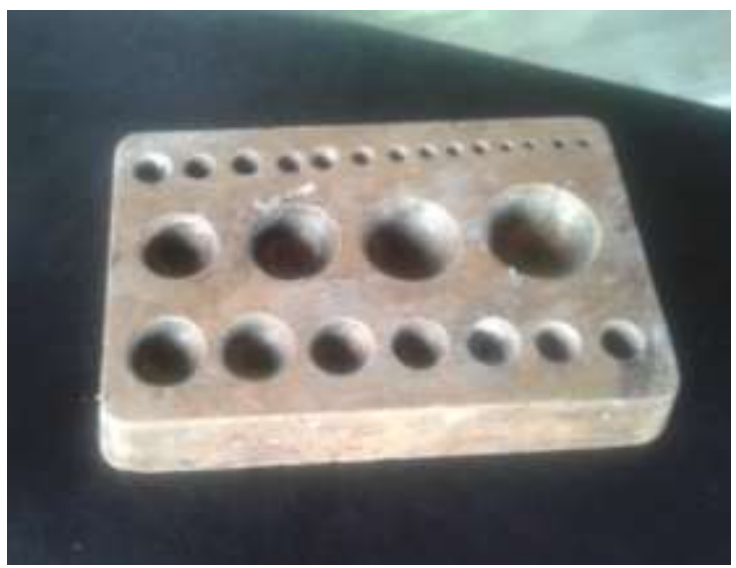

Gambar 4. Landasan Pembentuk

(Sumber Foto: Hendra, 2017) j. Kikir penghalus yang digunakan untuk merapikan bentuk;

k. j.Sikat kawat yang juga digunakan untuk membersihkan perak dari kotoran yang ada;

I. k. Gergaji skrol yang digunakan sebagai alat pemotong bagian yang sulit;

m. I. Timbangan yang digunakan sebagai pengukur perbandingan perak dan tembaga untuk di patri;

n. m. Wadah dari gerabah sebagai tempat peleburan biji perak;

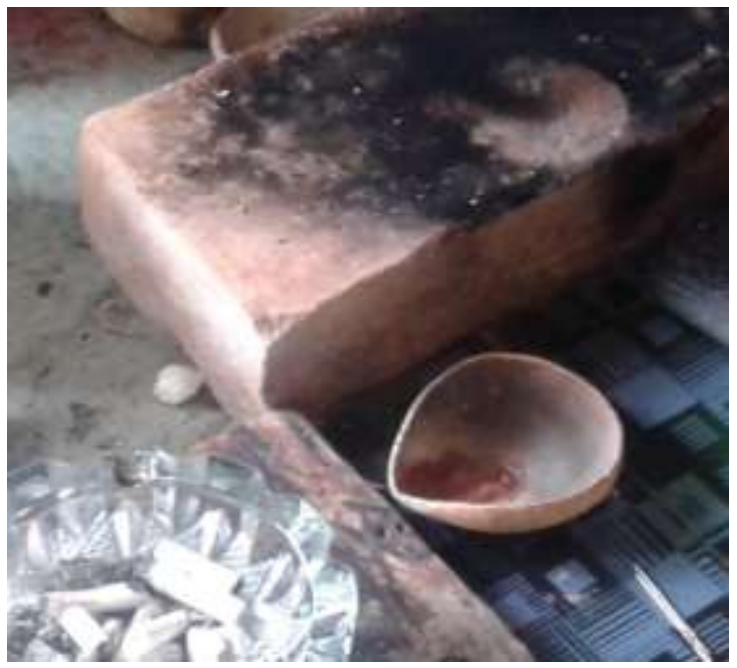

Gambar 5. Wadah Peleburan Biji Perak

(Sumber Foto: Hendra, 2017)

o. Pairik Bungkuak (tarikan bengkok) yang digunakan sebagai alat penarik dalam proses pembuatan kawat perak;

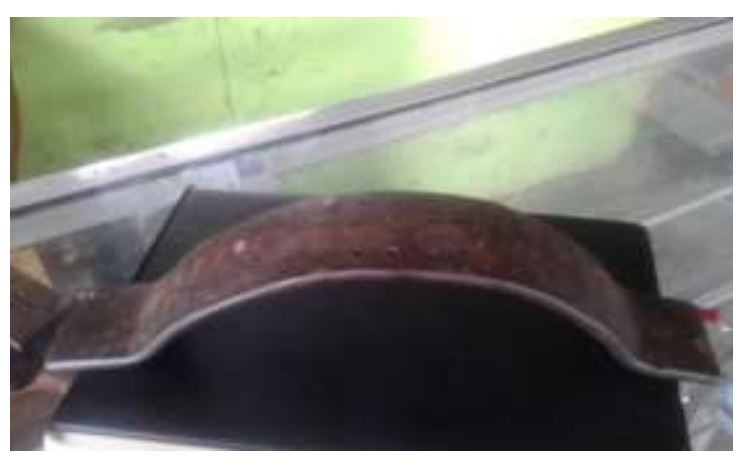

Gambar 6. Pairik Bungkuak

(Sumber Foto: Hendra, 2017)

Sedangkan bahan yang digunakan dalam proses pembuatan kerajinan perak adalah : 
a. Biji perak yang berbentuk butiran kecil dengan kadar 22 karat. Penggunaan perak murni merupakan komitmen bersama dari para perajin perak di Koto Gadang untuk menjaga kualitas produk yang dihasilkan;

b. Asam jawa yang digunakan untuk bahan pembersih;

c. Bahan Patri;

Patri merupakan salah satu teknik penyambungan logam. Patri terdiri atas dua jenis, yaitu patri lunak dan patri keras. Patri lunak menggunakan bahan berupa timah sebagai media penyambungnya, sedangkan patri keras menggunakan campuran antara perak dan tembaga dengan komposisi $60 \%$ perak dan $40 \%$ tembaga. Bagi perajin di Koto Gadang bahan patri yang terdiri atas perak dan tembaga yang terlebih dahulu dileburkan menjadi satu. Setelah menyatu, bahan patri ini kemudian dikikir menjadi serbuk yang halus yang nantinya akan ditaburkan pada bagian-bagian produk yang akan disambungkan. Untuk mempercepat penyatuan antara dua bagian perak yang dipatri, perajin menggunakan air pija (sejenis air tawas) yang diteteskan kepada bagian perak yang akan dipatri. Hal ini akan membantu mempercepat proses penyatuan antara bahan patri dengan perak yang dipatri.

Dalam proses pembentukan produk kerajinan perak Koto Gadang menggunakan beberapa teknik. Yang paling dominan adalah teknik felegree (tatrapan) yaitu teknik utama yang biasa digunakan oleh perajin perhiasan, baik itu dengan bahan baku emas maupun perak. Dalam proses pembuatan perhiasan dengan menggunakan teknik felegree memang membutuhkan kesabaran dan ketekunan. Hal ini dikarenakan perajin akan merangkai benang kawat perak yang halus satu demi satu untuk menghasilkan bentuk motif yang diinginkan (Kassim, 1990: 36). Selain teknik felegree, perajin juga menggunakan teknik pendukung di antaranya teknik tekan, teknik pahat, dan juga teknik cetak untuk beberapa produk tertentu. Untuk penyambungan antara bagian dari kawat perak tersebut digunakan teknik patri.

Teknik patri adalah penyambungan bagian-bagian logam dengan menambahkan cairan logam lainnya dengan suhu yang lebih rendah dari bagian logam yang disambung. Hal itu dapat dilakukan dengan baik jika waktu menyambungkan bagian logam tersebut dalam keadaan bersih, dan suhunya paling tidak sama dengan suhu logam patri (Sunaryo, 1997: 127). Proses penyambungan benang kawat perak dengan patri dilakukan sesuai dengan pesanan. Penyambungan perak dengan menggunakan patri keras menggunakan bahan logam dengan suhu bakar yang tinggi. Hasil dari patri keras ini akan memiliki daya tahan yang cukup kuat terhadap sambungan disebabkan adanya unsur senyawa antara bahan patri dengan benda yang akan dipatri.

Selanjutnya proses pembentukan produk adalah :

a. Menyiapkan Desain

Pembuatan desain merupakan proses awal yang perlu diperhatikan dalam membuat produk perak. Desain dan gambar lengkap dengan motif produk yang akan dibuat disiapkan di atas selembar kertas dan dari desain tersebut perajin dapat menentukan ukuran produk dan berat bahan perak yang dibutuhkan.

b. Menyiapkan Peralatan dan Bahan; peralatan dan bahan yang digunakan dalam pembuatan kerajinan perak ini disiapkan di ruang kerja.

c. Melebur Perak; kegiatan melebur perak dilakukan untuk mencairkan biji perak yang ada.

d. Membuat Kawat Perak

Biji perak yang akan dipakai dikumpulkan di dalam wadah keramik untuk kemudian 
dibakar sampai melebur. Setelah mencair tuangkan cairan perak tersebut ke dalam cetakan besi untuk kemudian membentuk lempengan/ batangan perak. Perak dalam keadaan panas tersebut kemudian dikeluarkan dari cetakan dan dilakukan penempaan dengan dipukul menggunakan palu besi. Pemukulan ini dilakukan sampai membentuk lempengan untuk menghasilkan kawat perak dan ada juga yang membentuk menjadi lembaran tipis untuk membentuk bunga dan lainnya. Untuk membentuk kawat perak, lempengan perak dimasukkan ke dalam lubang mal pembentuk dan kemudian diberi sedikit minyak agar lebih mudah ditarik. Setelah ditarik, akan terbentuk helai benang perak. Benang perak bisa dibuat dalam berbagai tingkat ukuran. Yang agak besar digunakan sebagai rangka dari perhiasan dengan ukuran diameter benang sekitar $2 \mathrm{~mm}$ atau 1,5 $\mathrm{mm}$. Sedangkan benang perak dengan diameter lebih halus, seperti $0,5 \mathrm{~mm}$ atau $0,3 \mathrm{~mm}$ digunakan untuk membentuk motif dari perhiasan perak tersebut.

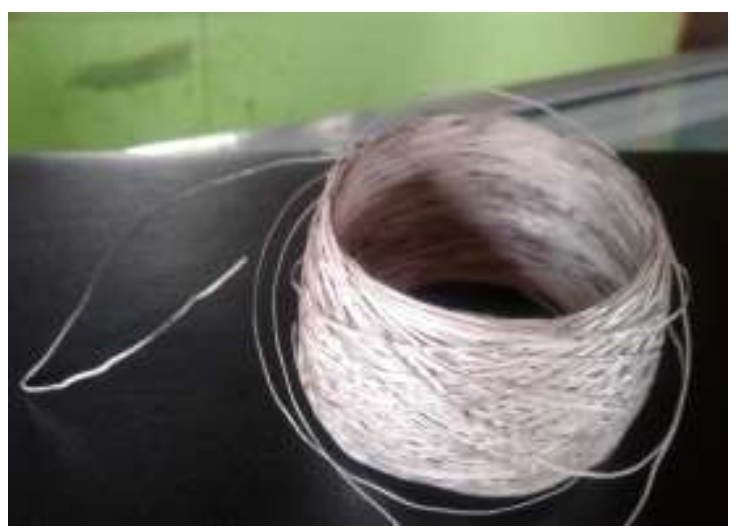

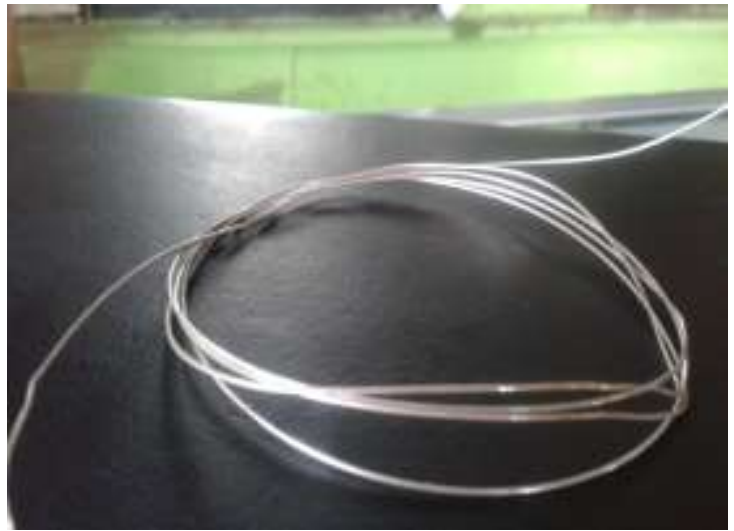

Gambar 7. Benang Perak dalam Berbagai Ikuran (Sumber Foto: Hendra, 2017)

e. Proses Perangkaian dan Pembentukan

Proses pembentukan dimulai dengan membentuk mal yang biasanya terbuat dari kertas dan kemudian kawat perak yang menjadi rangka disesuaikan dengan bentuk yang ada di mal kertas tersebut. Setelah terbentuk rangka yang dibantu dengan menggunakan tang pembentuk, dibuat beberapa rangka yang lainnya, sehingga proses ini bisa dikerjakan sekali jalan. Setelah rangka untuk bunga selesai, dilanjutkan dengan membentuk motif dengan benang perak yang ukurannya lebih halus.. Benang perak dibengkokkan dengan menggunakan pinset dan membentuk motif yang diinginkan. Proses ini memerlukan ketekunan dan ketelitian dari perajin untuk membentuk motif yang simetris dan terukur.

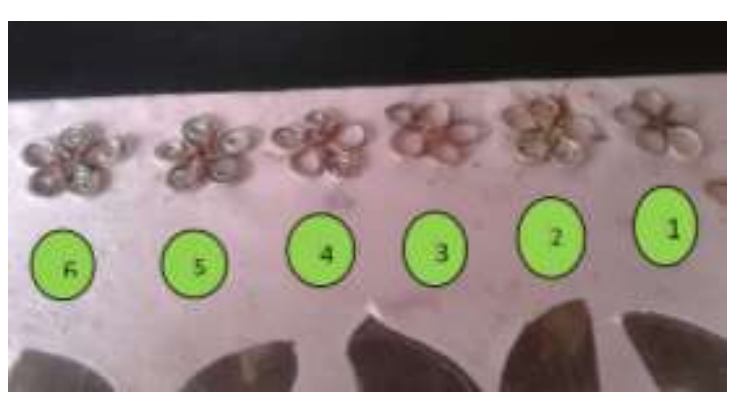




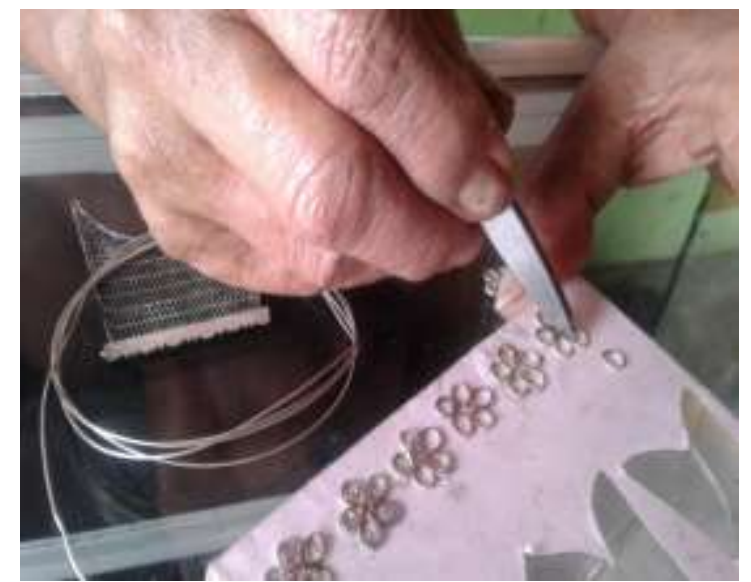

Gambar 8. Urutan Proses Pembentukan Rangka dan Motif dari Kanan ke Kiri

(Sumber Foto: Hendra, 2017)

\section{f. Proses Pematrian}

$$
\text { Proses pematrian merupakan }
$$

kegiatan menyambungkan antara bagian yang bersinggungan dari perhiasan, baik itu singgungan antara motif dan juga singgungan motif dengan rangka. Agar proses pematrian dapat selesai dengan cepat, biasanya dalam proses penyambungan diberi sedikit borak agar bahan perak dan tembaga cepat melebur. Setelah bahan patri melebur, baru dilakukan penempelan ke bagian yang akan dipatri tersebut.

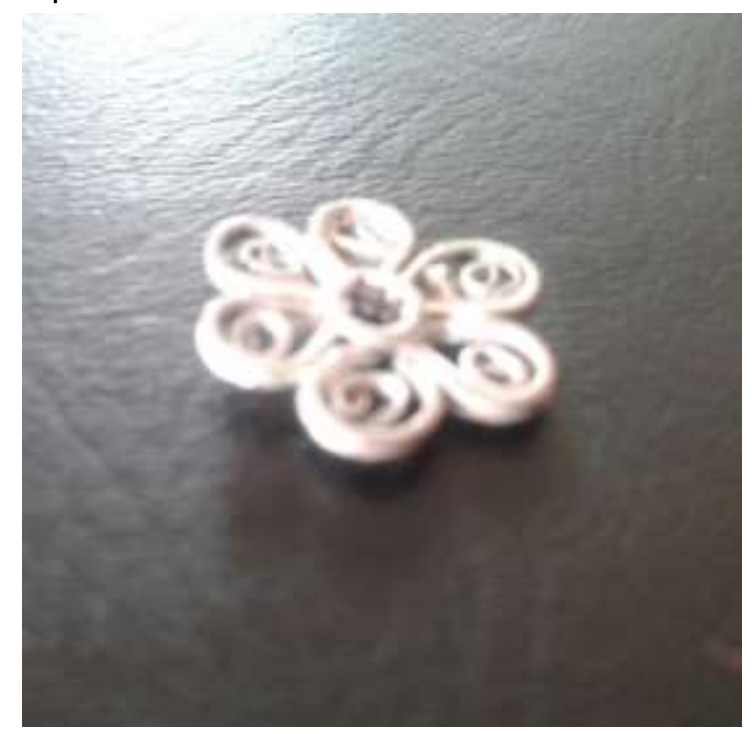

Gambar 9. Produk anting sudah selesai dipatri.

(Sumber Foto: Hendra, 2017)

\section{g. Proses Finishing}

Proses finishing bertujuan untuk memperhalus bentuk produk yang telah selesai dibentuk. Caranya dengan memasukkan produk yang telah dibuat ke dalam larutan yang berisikan air dan asam jawa, kemudian digosok dengan menggunakan sikat kawat kuningan. Selanjutnya produk dikeringkan dan dirapikan dengan menggunakan kikir halus untuk membuang bagian-bagian yang tidak diinginkan. Proses akhir dilakukan dengan membakar dengan menggunakan api kecil untuk menghilangkan sisa karbon dan dilanjutkan dengan menggosoknya dengan menggunakan kain yang lembut.

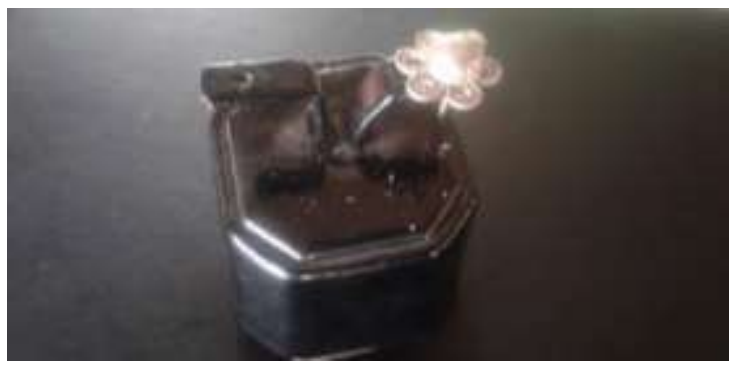

Gambar 10. Anting dari Perak

(Sumber Foto: Hendra, 2017)

\section{Bentuk Produk Kerajinan Perak Koto Gadang}

Produk kerajinan perak Koto Gadang memiliki beragam bentuk yang menunjukkan keragaman produk yang dihasilkan. Produk kerajinan ini ditujukan untuk berbagai kesempatan, seperti pesta pernikahan dan kegiatan kemasyarakatan lainnya. Produk yang dihasilkan dapat dikategorikan antara lain produk perhiasan dan souvenir. Produk perhiasan merupakan jenis produk yang paling sering dipesan untuk berbagai keperluan. Bentuk perhiasan antara lain kalung, gelang, cincin, dan bros. Produk tersebut memiliki beragam bentuk dan hiasan yang dikembangkan dari beragam motif yang ada. Dari fungsi sebagai hiasan ini akhirnya perak Koto Gadang menghasilkan beragam 
desain kerajinan perak yang unik. Kerajinan perak tersebut dibuat dengan menggunakan perak murni yang didesain sesuai dengan kebutuhan pasar. Bahkan di antara kebutuhan tersebut ada juga yang desainnya berasal dari keinginan konsumen yang kemudian diwujudkan dalam bentuk perhiasan perak.


Gambar 11. Beragam Jenis Perhiasan yang Dihasilkan

Selanjutnya ada juga bentuk kerajinan perak yang didesain sebagai benda pajangan atau sebagai souvenir dalam acara atau kegiatan tertentu. Kerajinan perak yang dihasilkan oleh perajin ini telah mengalami pergeseran fungsi dari hanya sekedar untuk perhiasan dan dalam upacara tertentu, kini produk yang dihasilkan telah berkembang menjadi produk cendera mata yang unik. Bentuk miniatur dari benda budaya menjadi inspirasi bagi perajin untuk menghasilkan beragam bentuk produk. Hal ini dapat dilihat dari beragam miniatur rumah gadang, miniatur jam gadang, dan benda budaya lainnya yang dibuat dari perak. Peluang usaha seperti ini muncul seiring dengan berkembangnya kota Bukittinggi menjadi ikon pariwisata Sumatera Barat. Hal ini menuntut perajin untuk lebih kreatif dalam mencari ide bentuk produk yang dihasilkan. Kemudian tercetuslah ide untuk membuat miniatur benda budaya dari perak yang bisa dijadikan sebagai buah tangan bagi wisatawan atau kenang-kenangan bagi pejabat pemerintahan yang datang.

Hasilnya beragam bentuk produk kreasi yang dihasilkan tersebut menjadi mahakarya yang sangat diminati oleh siapa saja. Harga dari produk kerajinan yang dihasilkan oleh perajin perak Koto Gadang relatif mahal, namun sesuai dengan kualitas yang dihasilkan. Seluruh produk kerajinan perak yang dihasilkan merupakan wujud eksistensi perajin dalam mempertahankan kerajinan tradisional terhadap gencarnya kemajuan zaman. 


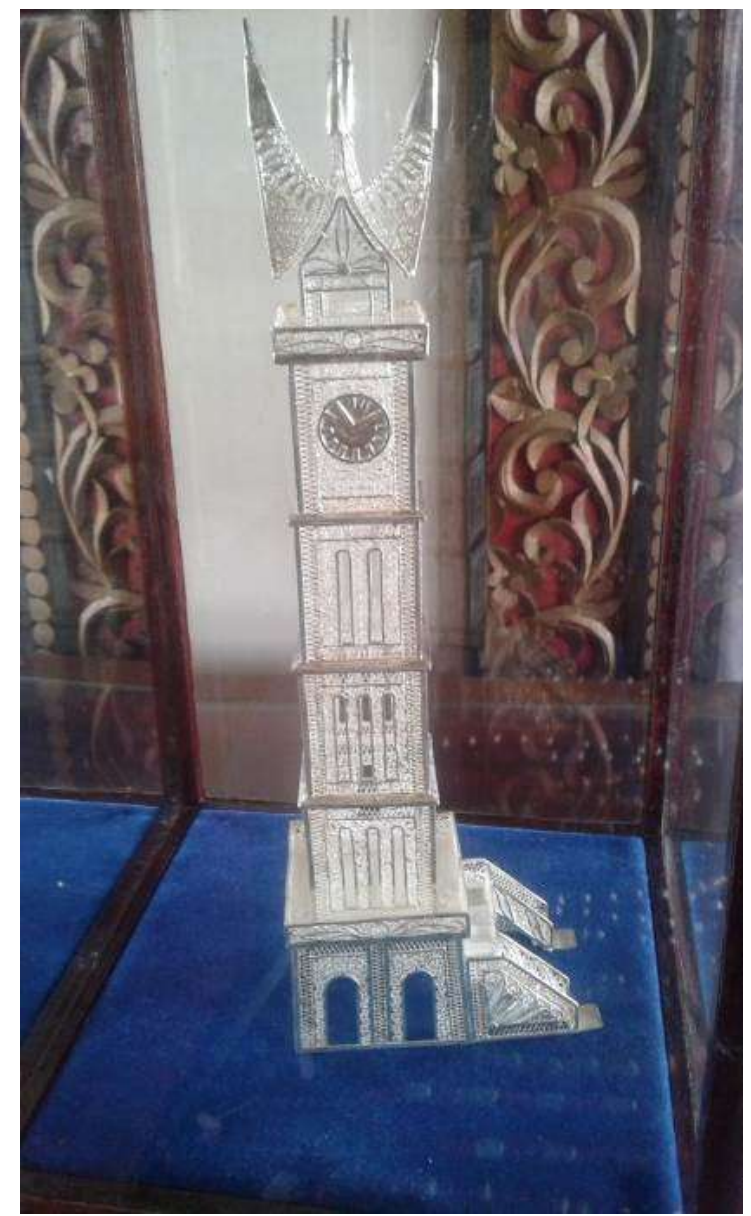

Gambar 11. Produk souvenir berbentuk jam gadang. (Sumber Foto: Hendra, 2017)

\section{Perkembangan Kerajinan Perak Koto Gadang}

Kerajinan perak Koto Gadang hadir seiring dengan lahirnya usaha Amai Setia. Kerajinan perak Koto Gadang biasanya didominasi oleh kaum lelaki dikarenakan pekerjaannya yang lebih membutuhkan tenaga dan kaum perempuan Koto Gadang lebih cenderung menyulam atau membuat songket dan rendo bangku. Keterlibatan perempuan hanya dalam bentuk membantu suami atau orang tua dalam proses pembuatan atau proses finishing. Apalagi sebelum adanya teknologi seperti kompor tembak sekarang, cara peleburan logam perak zaman dahulu dilakukan dengan alat pembakaran manual yang membutuhkan tenaga besar.
Namun sekarang sudah ada perajin perak yang dirintis oleh perempuan, seperti "Lili Indah Silverwork" yang didirikan oleh ibu Lili. Diawal merintis usaha, beliau memang memulainya dengan mendirikan usaha sulaman. Namun seiring berjalannya waktu beliau juga menerima orderan membuat kerajinan perak. Keahlian tersebut didapatkan dari orang tua yang juga perajin perak. Saat ini usaha bu Lili sudah mulai mendapat apresiasi dari wisatawan yang banyak memesan beragam bentuk produk kepada beliau. Hal ini menunjukkan bahwa perubahan budaya sangat mungkin terjadi sesuai dengan teori perubahan budaya Claire Holt yang mengemukakan perubahan budaya dalam perjalanan waktu adalah sesuatu yang wajar sejalan dengan perkembangan kehidupan masyarakat. Perubahan dari aspek tertentu dari budaya lama masih dimungkinkan karena masih dianggap relevan dengan zamannya. Biasanya perubahan terjadi akibat pengaruh dari dalam (internal) dan dari luar (eksternal) (1987: 33).

Perubahan juga terjadi pada bentuk kerajinan perak itu sendiri. Kalau di zaman dahulu kerajinan perak memproduksi produk perak yang sering dipakai untuk upacara pernikahan, seperti kalung, gelang, dan cincin perak. Jadi, setiap pengantin yang menikah di Koto Gadang akan mengenakan produk kerajinan perak yang dihasilkan oleh perajin Koto Gadang. Namun seiring perkembangan zaman, produk kerajinan perak Koto Gadang juga mengalami perkembangan yang menyesuaikan dengan kebutuhan zaman. Secara teoritis perubahan kebudayaan berkaitan erat dengan perubahan pola kebutuhan masyarakat pendukungnya, yaitu kebutuhan biologis, sosiologis, dan psikologis (Sjairin, 1992: 23).

Bentuk produk tradisi mulai dikembangkan seiring dengan permintaan dari konsumen yang ingin bentuk produk yang 
lebih variatif. Hal ini menjadi tantangan bagi perajin untuk bisa berkreasi menghasilkan produk yang sesuai dengan permintaan pelanggannya. Jika diamati dari sudut pandang ekonomi, peluang untuk berkembangnya usaha kerajinan perak Koto Gadang sangat menjanjikan. Hal ini didukung oleh beberapa faktor antara lain :

1. Koto Gadang masuk dalam kawasan destinasi wisata budaya, tempat lokasi Koto Gadang yang tidak terlalu jauh dari Kota Bukittinggi dan Ngarai Sianok, sehingga potensi pariwisata budayanya sangat besar.

2. Kerajinan perak Koto Gadang sudah ada semenjak puluhan tahun yang lalu, sehingga mnemiliki pondasi dan akar budaya yang sangat kuat.

3. Kerajinan perak Koto Gadang didukung oleh koperasi usaha yang dikenal dengan nama Amai Setia yang selalu siap mendukung dan membantu memasarkan setiap produk kerajinan yang dihasilkan oleh perajin. Apalagi sebagai unit usaha ekonomi, Amai Setia didukung oleh nama besarnya yang sudah dikenal luas oleh masyarakat, bahkan juga memiliki perwakilan usaha di Jakarta.

4. Kerajinan perak Koto Gadang merupakan satu-satunya sentra kerajinan perak yang ada di Sumatera bagian tengah. Hal ini tentunya membuat usaha kerajinan perak ini tidak memiliki pesaing.

5. Sistem pemasaran produk yang disepakati secara bersama oleh perajin adalah dengan menjual produk kerajinan perak hanya di Koto Gadang. Perajin ada yang membuat artshop sendiri di depan rumahnya, seperti yang dilakukan oleh "Leo Silverwork," atau menjualnya melalui koperasi usaha yang bernama Amai Setia. Penjualan hanya dilakukan di dalam lingkungan Koto Gadang dengan tujuan untuk menjaga kualitas produk yang dihasilkan (Wawancara dengan Lili di Koto Gadang, Tanggal 12 Oktober 2017). Hal ini mengingat membanjirnya produk perhiasan imitasi dengan harga murah di Kota Bukittinggi, sehingga sulit membedakannya dengan produk perak Koto Gadang. Oleh karena itu, jika konsumen ingin mendapatkan produk kerajinan perak Koto Gadang yang orisinal, mereka harus langsung mendatangi perajinnya di Koto gadang.

6. Para perajin perak Koto Gadang memiliki komitmen yang kuat untuk selalu menjaga produk kerajinan perak dengan kualitas baik atau menggunakan perak murni (Wawancara dengan Ari di Koto Gadang, Tanggal 23 Oktober 2017). Dengan adanya kesepakatan tak tertulis tersebut, membuat kualitas kerajinan perak Koto Gadang tetap bisa diandalkan dan konsumen akan mendapatkan produk berkualitas sesuai dengan tarif yang dipasang.

\section{PENUTUP}

Setelah melakukan penelitian dan beberapa kali melakukan pengambilan data di lapangan dapat diambil kesimpulan bahwa kerajinan perak Koto Gadang merupakan salah satu bentuk kerajinan tradisional yang ada di Sumatera Barat dan belangsung selama puluhan tahun. Kerajinan perak Koto Gadang lahir seiring berdirinya kerajinan Amai Setia yang berumur lebih dari seabad. Kerajinan perak muncul seiring kebudayaan yang dibawa oleh penjajah Belanda ke Indonesia. Kerajinan perak yang dahulunya didominasi oleh kaum lelaki, sekarang sudah mulai digeluti oleh kaum perempuan. Selain itu beragam bentuk serta fungsi kerajinan yang dihasilkan, disesuaikan dengan permintaan pasar. Hal ini membuktikan bahwa kerajinan perak Koto Gadang turut berkembang sesuai dengan perkembangan dan permintaan pasar. 
Kerajinan perak Koto Gadang selalu menjaga kualitas dari produk yang dihasilkan dengan tidak memasarkannnya keluar Koto Gadang. Perajin langsung memasarkan produk ke artshop yang ada di Koto Gadang. Hal ini untuk menjaga kualitas dari kerajinan perak Koto Gadang itu sendiri. Untuk jenis perhiasan yang dipasarkan keluar Koto Gadang hanya ke toko tertentu dan toko tersebut biasanya adalah toko emas dan perak. Mereka tidak menjual kepada pedagang biasa karena pedagang biasa akan sulit membedakan kualitas produk yang dihasilkan.

\section{DAFTAR PUSTAKA}

Feldman, Edmud Burke. 1967 Seni sebagai Ujud dan Gagasan, diterjemahkan oleh Sp. Gustami. 1991. Art As Image and Idea. Yogyakarta: Fakultas Seni Rupa dan Desain Institut Seni Indonesia Yogyakarta.

Gustami, SP. 1980. Nukilan Seni Ornamen Indonesia. Yogyakarta: STSRI “ASRI”.

2003. "Metode Pendekatan

dalam Kajian Seni Rupa." dalam Bunga Rampai Kajian Seni Rupa: Kenangan Purna Tugas Prof. Drs. Suwaji Bastomi. Semarang: UPT UNNES PRESS.

Haryono, Timbul. (Penyunting). 2009. Seni dalam Dimensi Bentuk, Ruang, dan Waktu. Jakarta: Wedatama Widia Sastra.

Holt, Claire. 1987. Art in Indonesia: Continuitas and change, terjemahan R.M. Soedarsono. New York: Cornelll Univesity Press.
Kassim, Moh. Ali. 1990. Barang Kemas Melayu Tradisi: Dewan Bahasa dan Pustaka. Kuala Lumpur: Kementerian Pendidikan Malaysia.

Koentjaraningrat. 1967. Pengantar IImu Antropologi. Jakarta: Aksara Baru.

Nawawi, Hadari.1990. Penelitian Bidang Sosial. Yogyakarta: Gajah Mada University Press.

Dewi, Razni Sita. 2005. Pakaian Tradisional Koto Gadang. Jakarta: Dian Rakyat.

\& Juni Mity j. 2011. Pakaian Tradisional Sulam, Tenun, \& Renda Khas Koto Gadang. Jakarta: Dian Rakyat.

Sairin, Sjafri. " Beberapa Catatan tentang Perubahan Kebudayaan Minangkabau" dalam buku Mestika Zed. Padang: Caesar Offset.

Soedarsono, R. M. 1999. Metodologi Penelitan Seni Pertunjukan dan Seni Rupa. Bandung: Masyarakat Seni Pertunjukan Indonesia.

Sunaryo, Hudi dan Sri A. Bandono. 1997. Pengetahuan Teknologi Kerajinan Logam I. Jakarta: Proyek Pengadaan Buku Pendidikan Teknologi Kerumahtanggaan dan Kejuruan Masyarakat.

Usman, Ibenzani. 1994. "Seni Ukir Tradisional pada Rumah Adat Minangkabau: Teknik, Pola dan Fungsinya." Disertasi sebagai salah satu syarat untuk memperoleh gelar Doktor. Bandung: Institut Teknologi Bandung. 